7. Кройчик Л.Е. Человек с молоточком. Вступительная статья. А.П. Чехов. Рассказы и повести. М., 1982. С. 5-23.

8. Покровская Е.А. Экспрессивность эллиптических конструкций с прямой речью в прозе А. П. Чехова. Языковое мастерство А.П. Чехова. Ростов-на-Дону, 1990. С. 89-95.

9. Татарникова Г.Ф. Слова чужого словаря как выразительно-изобразительное средство в произведениях А.П. Чехова. Языковое мастерство А.П. Чехова. Ростов-на-Дону, 1990. С. 103-107.

10. Чехов А.П. Рассказы и повести. М. : Изд. ВГУ, 1982. 480 с.

11. Чехов А.П. Полное собрание сочинений. М. : Наука, Т. 3, 1983. 619 с.

12. Чехов А.П. Полное собрание сочинений. М. : Наука, Т. 6, 1985. 733 с.

13. Чехов А.П. Первый любовник. М. : Изд-во АСТ, 2003. 347 с.

14. Чехов А.П. Рассказы. 1887. М. : Наука, 1974. 297 с.

15. Чехов А.П. Рассказы. Юморески. 1885-1886. Полное собрание сочинений и писем. Режим доступа (01.09.2019): https://www.e-reading.club/book.php?book=64054.

УДК 811.161.1

DOI https://doi.org/10.32782/tps2663-4880/2019.11-1.14

ЯЗЫКОВЫЕ РЕФЕРЕНТЫ ПОНЯТИЯ ОТСУТСТВИЕ В РУССКОМ ЯЗЫКЕ МОВНІ РЕФЕРЕНТИ ПОНЯТТЯ ВІДСУТНІСТЬ У РОСІЙСЬКІЙ МОВІ

\title{
LANGUAGE REFERENTS OF THE NOTION OF ABSENCE IN THE RUSSIAN LANGUAGE
}

\author{
Радчук О.В. \\ orcid.org/0000-0002-0343-6796 \\ кандидат филологических наук, дочент, \\ доиент кафедры славянских языков \\ Харьковского национального педагогического университета \\ имени Г.С. Сковороды
}

Исследование посвящено рассмотрению понятия отсутствие в лексико-семантической системе языка и средств его репрезентации в русском языке. Используя методики концептуального анализа и интерпретации, подтверждается гипотеза о том, что лексические средства выражения понятия отсутствия появились в силу семантической неполноты языковых прототипов нет и без, поскольку они не выражали субъективных нюансов, которые приобрели конкретные слова.

Опираясь на понятие апперцепции как мыслительной операции, были установлены связи между прототипом и новой номинацией. Результаты анализа последовательно представлены в таблице «Лингвальные репрезентанты понятия отсутствие», которая наглядно демонстрирует аномальные фррагменты языковой системы и, в частности, указанного явления.

Материалы толковых, этимологических, словообразовательных и других лексикографических источников позволили сделать вывод о том, что формирование понятия отсутствие в разных словах происходит неодинаково. Новое слово может быть создано на основе существующих словообразовательных моделей, но в одних словах сема «отсутствие» заложена уже в корневой морфеме, а в других такая сема передается с помощью афрфиксов.

Появление в русском языке заимствованных слов, передающих понятие отсутствие, связано с взаимовлиянием языков, проявлением межъязыкового лингвокультурного трансфера. В других языках, даже не родственных, потребность в выражении данного абстрактного понятия появилась раньше под влиянием экстралингвальных фракторов.

Несмотря на высокий экспланаторный потенциал понятия отсутствие, семантика слова не всегда может быть объяснена с помощью данного понятия. Иногда значение мотивировано понятием наличие, которое демонстрирует бинарную оппозицию анализируемого понятия. Рассмотренные особенности русского языка, отражающие отсутствие номинаций, в которых не нашли воплощение прототипы нет и без, образуют лакуны в ее лексикосемантической системе, в частности в репрезентации понятия отсутствие.

Ключевые слова: когнитивная лингвистика, система языка, абстрактное понятие отсутствие, прототипы нет и без, методики концептуального анализа и интерпретации.

Дослідження присвячено розгляду поняття відсутність у лексико-семантичній системі мови й засобів його репрезентації в російській мові. Використовуючи методики концептуального аналізу та інтерпретації, підтверджується гіпотеза про те, що лексичні засоби вираження поняття відсутності з'явилися внаслідок семантичної неповноти мовних прототипів немає і без, оскільки вони не виражають суб'єктивних нюансів конкретних слів. 
Спираючись на поняття апперцепції як розумової операції, встановлені зв'язки між прототипом і новою номінацією. Результати аналізу послідовно представлено в таблиці «Лінгвальні репрезентанти поняття відсутність», яка наочно демонструє аномальні фрагменти мовної системи щодо зазначеного явища.

Матеріали тлумачних, етимологічних, словотворчих та інших лексикографічних джерел надали можливість зробити висновок про те, що формування поняття відсутність у різних словах відбувається неоднаково. Нове слово може бути створено на основі існуючих словотворчих моделей, але в одних словах сему «відсутність» закладено вже в кореневу морфему, а в інших така сема передається за допомогою афіксів.

Виникнення в російській мові запозичених слів, що передають поняття відсутність, пов'язане із взаємовпливом мов, виявом міжмовного лінгвокультурного трансферу. В інших мовах, навіть не споріднених, потреба у вираженні даного абстрактного поняття з'вилася раніше під впливом екстралінгвальних фракторів.

Незважаючи на високий експланаторний потенціал поняття відсутність, семантика слова не завжди може бути пояснена за його допомогою. Іноді значення мотивується поняттям наявність, що демонструє бінарну опозицію аналізованого поняття. Розглянуто особливості російської мови щодо відсутності номінацій, у яких не знайшли втілення прототипи немає і без, що становить певні лакуни в її лексико-семантичній системі, зокрема в репрезентації поняття відсутність.

Ключові слова: когнітивна лінгвістика, система мови, абстрактне поняття відсутність, прототипи немає і без, методики концептуального аналізу та інтерпретації.

The research deals with the notion of absence as one of the basic notions in cognitive linguistics and the means of its representation in the Russian language. By using the conceptual analysis and interpretation techniques, the hypothesis is confirmed that the lexical means of expressing the notion of absence appeared due to semantic incompleteness of linguistic prototypes no and without, because they did not express the subjective nuances of certain words.

Based on the concept of apperception as a mental operation, there were established links between the prototype and a new nomination. The analysis results are presented in the table "Lingual representations of the concept of absence". Empty cells in the table clearly demonstrate anomalous fragments of the language system concerning the phenomenon mentioned above.

The data drawn from monolingual, etymological, derivational and other lexicographical sources enables the researcher to conclude that the formation of the notion of absence in different words takes place in different ways. A new word can be coined by already existing word-building patterns but in some words the seme of absence is expressed by the root morpheme while in some others it is expressed by the affixes.

Appearance in the Russian language of borrowed words that convey the notion of absence is associated with the mutual influence of languages, the manifestation of interlingual linguocultural transfer. In other languages, even non-cognate ones, the need to represent this abstract notion appeared earlier under the influence of extralingual factors.

Despite the high explanatory potential of the notion of absence, the semantics of a word cannot always be explained with the help of this notion. Sometimes the meaning is motivated by the notion of presence, thus demonstrating the binary opposition to notion of absence. The article considers the Russian language specifics as to the absence of nominations, in which the prototypes no and without have been embodied. It makes up certain empty cells in its lexico-semantic system, in representing the notion of absence in particular.

Key words: cognitive linguistic, language system, the abstract notion of absence, prototypes no and without, conceptual analysis and interpretation techniques.

Среди языковедов бытует мнение о том, что лингвальная единица возникает благодаря существованию понятия, потому что у говорящего появляется потребность выразить это понятие. Однако вербальная экспликация происходит по-разному. Прежде чем появится конкретное слово, в котором четко отразится определенное семантическое ядро, будут использоваться прототипические языковые ресурсы, уже имеющиеся в языке и закрепленные речевой практикой. Новое слово может быть создано, образовано на основе существующих словообразовательных моделей, но может быть и заимствовано из другого языка, даже не родственного, в котором потребность в выражении данного абстрактного понятия появилась раньше под влиянием экстралингвальных факторов.

Цель статьи состоит в анализе вербальной экспликации абстрактного понятия отсутствие, установлении связей между прототипом и семантическим ядром лексемы, репрезентирующей данное понятие, а также рассмотрении случаевисключений из общей плоскости наблюдений.

Актуальность темы обусловлена интересом современных когнитивных студий к изучению универсальных и специальных способов языкового выражения абстрактных понятий, отражающих национальную ментальность носителей конкретного языка, в данном случае - русского.

Научный интерес, на наш взгляд, представляют наблюдения лингвиста-когнитолога А.Д. Кошелева о том, что абстрактная лексика имеет большое количество языковых репрезентаций. Ученый считает, что «при переходе к изучению абстрактных лексических значений необходимо, прежде всего, ответить на вопрос: сохраняется ли для них дуальная структура «Прототип $\longleftarrow$ семантическое Ядро», присущая основным значениям сенсорной лексики?» [1, с. 145]. Логическим итогом наблюдений ученого является следующий ответ: «Главный компонент - «семантическое ядро», 
реализующее ту же референциальную, или номинативную, функцию, у основного значения абстрактного слова всегда имеется» [1, с. 145]. Выделение же прототипического компонента, по мнению языковеда, факультативно. Основное значение чаще представлено только семантическим ядром, хотя бывают случаи, когда именно прототипическое значение выполняет смыслоразличительную функцию и кристаллизуется ядерная сема. На наш взгляд, в вербальной репрезентации понятия отсутствие прототипический элемент значения переносится и воспроизводится в ядерной семе слов, обозначающих конкретное отсутствие чего-либо. Этот процесс связан с апперцепцией, поскольку языковой факт проявляется не мгновенно, а сопряжен с творческим процессом осмысления социального опыта человеком, механизм восприятия и познания одного и того же объекта сохраняет прежний опыт, но в то же время фиксирует новое знание и представление об этом объекте. Когнитивная лингвистика, как и современная психология, в описании процесса познания опирается на понятие апперцепции, введенное в языкознание А.А. Потебней.

В новом освещении концепции Ф. де Соссюра и его понимании знакового характера языка О.П. Просяник указывает на то, что «восприятие целостного акустического образа должно вступить в знаковые отношения с формами, которые уже существуют в конкретном языке, а это может случиться только в том случае, когда у говорящего есть потребность высказать, выразить в языковой форме мысль (понятие), для которого в этом языке еще нет лингвальной единицы» (Перевод наш - O.P.) [2, с. 169].

Наши размышления, касающиеся причинно-следственных связей прототипов не и без, уже были изложены в статье «Лексикограмматическая корреляция абстрактных понятий (отсутствие - отрицание - пустота)» [3], а новые собранные языковые факты не только подтверждают наши выводы, но и позволяют развить нашу идею и сделать другие умозаключения.

Составленная нами исследовательская картотека представлена в виде таблицы (Таблица 1), в которой большинство примеров явно обнаруживают корреляционные отношения с прототипами нет и без, однако встречаются и такие, в которых эти связи нарушены. Рассмотрим каждый пример подробнее.

Слово одинокий определяет человека (мужчину, женщину), не имеющего близких, родных или такого, который находится в отсутствии других. Как известно, в русском языке полные формы адъективов развились из кратких, первоначально было прилагательное одинок, состав слова состоял из корня один и суффикса -ок, позже присоединилась флексия. В качестве синонима в современном языке используется адъектив уединенный. В русской языковой ментальности представление об одиночестве связано с чувствами жалости и сочувствия. Появившиеся сложные номинации мать-одиночка и позже отец-одиночка констатируют факт неполной семьи, трудности, связанные с воспитанием ребенка только матерью или только отцом, поскольку одному человеку приходится выполнять самому функцию, возлагаемую на обоих родителей. В украинском языке эквивалентом русскому слову одинокий является слово самотній, в котором акцент делается на том, что человек живет сам, один. У европейцев ментальность иная, в Европе наблюдается глобализация жизни-соло, стремительно увеличивается число семей, состоящих из одного человека, зачастую европейцы в качестве модели личной жизни выбирают автономность и не видят в этом ничего негативного. У носителей русского языка и других славянских народов изначально было заложено стремление к коллективному существованию, образованию семьи, все это откладывало отпечаток и на язык.

Таблица 1

Лингвальные репрезентаты понятия отсутствие

\begin{tabular}{|c|c|c|}
\hline Репрезентант нет & Лексема & Репрезентант без \\
\hline нет близких & одиокий & без близких \\
\hline нет обуви & босой & без обуви \\
\hline нет дома & беженец & без дома \\
\hline нет жизни & мертвец & без жизни \\
\hline нет порядка & хаос & без порядка \\
\hline нет ума & идот & без ума \\
\hline & гений & \\
\hline & жалость & без детей \\
\hline
\end{tabular}


Лексема босой встречается не во всех толковых словарях, поскольку носителям русского языка понятно, что это человек без обуви, человек, у которого нет обуви, и это не свойственно для современного общества. Здесь прослеживается влияние европейской культуры на славянскую, наличие перчаток, закрытой обуви является составной частью этикета, а их отсутствие в деловом костюме считается нарушением этикетных формул, неприличным для посещения официальных мероприятий. Интересные исторические сведения об анализируемой лексеме находим в словаре В.И. Даля. В качестве синонимов к слову босой выступают слова босоногий, голоногий, необутый. Приводится иронический исконно русский фразеологизм к босому по лапти пошел, в котором ярко прослеживается отсылка к понятию отсутствие. Слово босой так же, как и слово голый, имеет негативную коннотацию в русской языковой ментальности, что подтверждают сведения, приводимые в словаре В.И. Даля. Причем слово босой могло характеризовать не только человека, но лошадь и других парнокопытных. Нищенское существование человека отождествляло его с животным, понижая его статус, может быть, поэтому наличие хорошей, качественной обуви всегда выделяло человека из толпы. Производящая основа бос адъектива босой обладает хорошим деривационным потенциалом, поскольку от данной основы могут быть образованы субстантивы и глаголы, а также может наблюдаться процесс субстантивации слова босой. В словарной статье, посвященной данной лексеме, приводятся субстантивы, образованные от адъектива босой, и указывается, что «босота, босина, босоножье - нагота ног, состояние без обуви; голь, нужда, в значении нищеты. Босая лошадь - с плохими, слабыми копытами, противоположное обувистая» [5, с. 75], босва, босовь могут обозначать в некоторых диалектах ступню человека, слова босовики, босики, босоноги употребляются во множественном числе и обозначают «опорыши, башмаки из старых сапогов, обувь на босу ногу, [...] берестеники, берестовые лапти на босу ногу, для дома» [5, с. 76], бедняков без обуви, оборванцев называли босомыка/ босомыга, босыня, босомыюник/босомыжница. Отсюда и глаголы «босеть - обнашиваться обувью, становиться без обуви; голеть, беднеть, нищать. Босеть о лошади, скоте - болеть ногами, копытами» $[5$, с. 76]. Слово босяк изменило свое значение и в разговорном стиле современного русского языка приобрело пейоративную коннотацию. В лексиконе народа были и слова, име- ющие ироничную коннотацию, построенную на метафоре. К таким словам относятся образные субстантивы «босопляс, босохлест, босуля - человек, никогда не носящий обуви, всегда босой; бежать босоплясом - босиком, особенно в грязи или по снегу» [5, с. 76]. Носителей славянских языков всегда отличало душевное отношение к босым людям, чувство сострадания к нищим, люди без обуви вызывали сочувствие и жалость.

Аналогичное отношение прослеживается в славянской культуре и к следующим словам: беженеи и мертвеи. Субстантив беженеи имеет словообразовательный формант, передающий агентивное значение. Как указывается в грамматиках, такие субстантивы мотивированы глаголами и имеют значение «носитель процессуального признака». В слове беженеи, которое представляет собой исключение в деривационном аспекте, выделяется единичный непродуктивный суффикс -енеи. Субстантив мертвеи образовано от адъектива путем присоединения частотного продуктивного суффикса -ец [6, с. 145]. Понятие отсутствие реализовано в данных примерах по-разному. Слово беженеи становится репрезентантом понятия отсутствие только при достижении семантической и грамматической оформленности и целостности слова, то есть с присоединением суффикса -енеи. Имена существительные, образованные от глаголов, с другими суффиксами (бег, бегун, бегунья, бегство) не передают понятие отсутствие. В слове же мертвец словообразовательный формант не играет роли в передаче значения «отсутствие жизни», понятие отсутствие содержится уже в корневой морфеме. Однокорневое слово смерть обозначает «прекращение жизнедеятельности организма» и восходит, как и анализируемое слово, к индоевропейскому праязыку [7, с. 386]. Например, в санскрите существовало слово амрита, которое обозначало «нектар, способный оживить человека». Ассоциативно это связано с тем, что мертвого человека, то есть лишенного признаков жизни, возможно реанимировать, чего нельзя сделать с трупом, и, как, следствие, слово мертвец относится наряду со словом покойник к одушевленным именам существительным, а слово mpyn - к неодушевленным: в форме винительного падежа вижу (кого?) мертвеща, покойника, но вижу (что?) труn. Для носителей русского языка данный грамматический факт является одним из самых непонятных, и он обычно относится к аномальным явлениям.

Для конкретизации абстрактного понятия отсутствие не всегда возникало новое слово, 
проще было его заимствовать, если оно уже существовало в другом языке. Как раз в таком заимствовании наблюдается взаимовлияние языков, проявление лингвокультурного трансфера.

Древнегреческие слова омонимы Xaoc (Chaos) и $x a o c$ (chaos) в зависимости от значения, которое в русском языке дифференцировалось с помощью ударения, обозначали, в первом случае, с ударением на первом гласном, «в древнегреческой мифологии зияющая бездна, наполненная туманом и мраком, из которой произошло все существующее», а во втором - с ударением на втором гласном, «полный беспорядок, неразбериха» [8, с. 558]. Семантика образованных от второго омонима адъективов хаотический и хаотичный «представляющий собой хаос, беспорядочный, перепутанный, лишенный стройности, системы» [8, с. 558] - передает характеристики, напрямую связанные с понятием отсутствие и прототипами нет и без (нет порядка и без порядка).

Слово идиот пришло в русский язык также из древнегреческого, имеет общий корень со словом идиома, в античности употреблялось в значении «отдельный», т.е. не такой, как все. У древних эллинов идиотами называли мужчин, которые не принимали участия в дружеских пирушках, людей, которые сторонились общества, жили обособленно. Естественно, их считали малоумными, хотя они, напротив, противопоставляли себя, свои идеи общественному мнению и считали себя намного умней остальных. Определяя этимологию и развитие значения слова идиот, А.Г. Ильяхов в книге «Античные корни русского языка» пишет, что впервые анализируемую номинацию в современном понимании употребил врач Парацельс в 1526 году в значении «безумный, сумасшедший» [9]. В современном русском языке на базе первичного значения «человек, который страдает слабоумием, идиотизмом» развилось вторичное «глупый человек, тупица, дурак (разг., бран.)» и появился субстантив, используемый в форме женского рода - идиотка [10, с. 194]. Данная лексема, хотя и имеет сниженную коннотацию, передает пренебрежительно-уничижительный оттенок, тем не менее относится к достаточно распространенной лексике.

Несмотря на высокий экспланаторный потенциал понятия отсутствие, не всегда и не все вербальные экспликации можно объяснить с помощью данного понятия. Лексема гений, начиная с эпохи Возрождения употребляющаяся в значении «творческая индивидуальность», была заимствована в русский язык в эпоху Петра I из немецкого (Genius) и восходит к латинскому (genus).
Данный субстантив, в отличие от предыдущего заимствования, не может быть объяснен с помощью понятия отсутствие. Напротив, слово гений характеризуется с помощью понятия наличие, и определяется как «человек, обладающий высшими творческими способностями» [7, с. 79]. Особенностью данной языковой единицы является и то, что она используется в русском языке только в форме мужского рода, что является проявлением значения понятия отсутствие на грамматическом срезе языка. В этом и аналогичных примерах наблюдается влияние семантики на грамматику.

Как показывают многие примеры, заимствования наблюдаются в двухвекторной плоскости: по признаку отсутствие и по признаку наличие. Однако это касается не только заимствований. Например, субстантив русского языка жалость образован от адъектива жалкий, восходящего к общеславянскому имени существительному жаль, семантика которого «жалость, печаль, тоска» $[7$, с. 126]. Гипотетически возможно определение значения слова жалость посредством использования прототипов нет и без и антонима радость, но семантика глаголов, с которыми исследуемое слово генетически связано, не позволяет этого сделать. В этимологической справке приводятся следующие сведения: «Праслав. *gelъ образовано с пом. темы -ъ от глагола *gelti «страдать». Ср. с гласн. -е-: др.рус. и ст.-сл. желА < желја «скорбь, плач», желение «сожаление; плач»; в.-луж. zel «жаль»; болг. жалба «сожаление, горе»; лит. gela «боль», gelus «жалкий». Сущ. жаль «скорбь» дало с суф. -Ђ-mu глаг. жальти < жалеть «проявлять жалость, сострадание к кому-либо, оберегать, щадить», от глаг. с суф. -об-а сущ. жалоба «сетование», «заявление о незаконном действии со стороны кого-то» [7, с. 126]. Исторические факты подтверждают нашу мысль о том, что объяснительный потенциал понятия отсутствие имеет ограничения.

Необходимо уточнить, что прототипы нет и без могут не найти своей вербальной экспликации в конкретном слове. В русском языке не существует номинации, обозначающей женщину без детей, у которой нет детей. В древности в русском языке использовалось слово неродица, которое в настоящее время вышло из употребления и относится к архаической лексике. В словарном составе языка есть субстантивированные адъективы, в структуру которых входят префиксы не- и бес-: неплодная и бесплодная, но отдельная лексема отсутствует. По отношению к животному и растительному миру в таких случаях употре- 
бляется слово яловая. В словаре В.И. Даля указывается, что «яловая - не стельная, не суягняя, не жеребая, без приплоду, порозжая, праздная; не давшая еще приплоду. Яловая рыба - без икры. О дереве либо кусте: бесплодный, не дающий плода. Порожний, пустой, не в деле, лежащий впусте. Яловые земли - покинутые надолго в залежь» [5, с. 734$]$.

Интересным представляется наблюдение о том, что и в других языках либо не существует такой номинации, прототипами которой являлись бы выражения нет детей и без детей, либо она используется редко. Можно предположить, что в данном случае понятие отсутствие является языковой универсалией. Наиболее употребительным в английском языке является слово childless, которое обозначает «бездетный», употребляется по отношению к женщине или семейной паре. Несуществование номинации, обозначающей бездетную женщину, в русском языке связано с тем, что в славянском этносе первое и главное предназначение женщины состоит в детородной функции, естественным и логичным является наличие у женщины детей, ее способности продолжить род.

Современные исследования фиксируют существующие языковые факты. Однако отметим, что язык находится постоянно в движении и предсказать перспективы изменений невозможно. Будут ли заполнены «ниши», «пустые ячейки» в лексико-семантической подсистеме языка, утверждать однозначно нельзя.

Подводя итоги, мы можем сделать следующие выводы: существующие в русском языке прототипы понятия отсутствие нет и без в большинстве случаев развились в новые номинации, выражающие данное понятие; слова, непосредственно или косвенно определяемые с помощью понятия отсутствие, чаще передают негативную коннотацию, которая может иметь различную степень проявления; не все номинации могут создаваться из необходимости выразить понятие отсуmствие, такие слова могут заимствоваться; не все слова могут определяться посредством понятия отсутствие; не всегда прототипы нет и без могут воплощаться в новой лексеме.

\section{СПИСОК ИСПОЛЬЗОВАННЫХ ИСТОЧНИКОВ:}

1. Кошелев А.Д. Когнитивный анализ общечеловеческих концептов. Москва : Рукописные памятники Древней Руси. 2015. 280 с.

2. Просяник О.П. Фердинанд де Соссюр: деміфологізація концепції: монографрія. Харків : Харківське історико-фрілологічне товариство. 2018. 276 с.

3. Радчук О.В. Лексико-грамматическая корреляция абстрактных понятий (отсутствие - отрицание пусmoma). Studia methodological, Ternopil Volodymyr Hnatiuk National Pedagogical University, Jan Kochanowski University in Kielce, Issue 41, 2015, P. 17-23.

4. Даль В.И. Толковый словарь русского языка: современная версия. Москва : Эксмо. 2010. 736 с.

5. Русская грамматика / [Гл. ред. Н.Ю. Шведова]. В 2-х т. Т.І. Фонетика. Фонология. Ударение. Интонация. Словообразование. Морфология. Москва : Наука. 1980. 784 с.

6. Цыганенко Г.П. Этимологический словарь русского языка. 2-е изд., переаб. и доп. Київ : Рад. шк. 1989. 511 с.

7. Словарь иностранных слов. 18-е изд. Москва : Рус. яз. 1989. 624 с.

8. Ильяхов А.Г. Античные корни русского языка. Этимологический словарь. Ростов н/Д : Феникс, 2006. 320 с.

9. Ожегов С.И. Словарь русского языка: Ок. 57000 слов / Под ред. чл.-корр. АН СССР Н.Ю. Шведовой. 19-е изд., испр. Москва : Рус. яз., 1987. 750 с. 